\title{
CRYPTOCURRENCY DALAM PERSFEKTIF SYARIAH: SEBAGAI MATA UANG ATAU ASET KOMODITAS
}

\author{
Khairunnisa Harahap ${ }^{1)^{*}}$, Tuti Anggraini ${ }^{2)}$, Asmuni ${ }^{2)}$ \\ 1) Fakultas Ekonomi, Universitas Negeri Medan \\ *Penulis Korespondensi: nisaharahap77@gmail.com, tutianggraini@uinsu.ac.id, asmuni@uinsu.ac.id
}

\begin{abstract}
Fenomena Cryptocurrency yang dapat digunakan sebagai alat pembayaran, Investasi, maupun Trading menjadi trending topik yang sangat banyak dibicarakan. Tujuan penelitian ini ingin mengkaji bagaimana cryptocurrency di lihat dari persfektif syariah. Masalah dalam penelitian ini adalah pro dan kontra di masyarakat terjadi akibat perbedaan pendapat mengenai Cryptocurrency. Karena belum ada legalitas mengenai Cryptocurrency sebagai alat pembayaran maupun mata uang yang diakui di Indonesia. Harganya yang Fluktuatif serta keamanannya yang masih terdapat cela membuat perdebatan mengenai Cryptocurrency seperti pada Bitcoin belum mencapai titik terang. Dalam Perspektif hukum islam, sebagian Ulama dan MUI berpendapat bahwa bentuk mata uang digital ini tidak mempunyai kejelasan dan tidak dapat dilihat fisiknya memungkinkan terjadinya penipuan menjadikan Cryptocurrency mengandung unsur Gharar. Kemudian penggunaan Cryptocurrency dalam Investasi maupun Trading menjadikannya tidak lepas dari spekulasi mengenai harganya yang sangat Fluktuatif dan hanya digunakan sebagai alat untung rugi maka Cryptocurrency mengandung unsur Maysir. Karena urgensi mata uang Kripto ini sangat luas terutama dalam cakupan teknologi dan ekonomi. Penelitian ini akan menggunakan penelitian kualitatif dengan studi literatur dan pendekatan ushul fikih yang bersumber dari Alqur"an, Hadits dan Qiyas. Penulis menyimpulkan bahwasanya secara teknis dan praktek crytocurrency tidak bisa dinyatakan sebagai mata uang, sedangkan cryptocurrency sebagai dapat dinyatakan aset komoditas jika, mengandung nilai manfaat dan memiliki underlying asset. Jika syarat tersebut tidk terpenuhi maka haram hukumnya.
\end{abstract}

Kata Kunci: Cryptocurrency, Bitcoin, Criptocurrency sebagai mata uang dan Criptocurrency sebagai Aset Komoditas.

Article Information:

Received Date: 21 Januari 2022

Revised Date: 7 Februari 2022

Accepted Date: 21 Februari 2022 


\section{PENDAHULUAN}

Pada era digitalisasi saat ini, memunculkan teknologi yang canggih dalam beberapa bidang kehidupan manusia untuk menjalankan aktivitasnya--tak terkecuali kecanggihan yang dapat kita rasakan dalam transaksi jual beli-- hanya dengan melalui internet. Internet telah menjelma menjadi sarana pilihan populer dengan segala kemudahan dan kecepatan yang diberikan. Era digital economics 4.0 ialah era yang ditandai dengan maraknya pemanfaatan internet sebagai media komunikasi, transaksi dan kolaborasi. Perdagangan melalui dunia maya ini terkenal dengan istilah e-commerce. Uang digital atau elektronik merupakan alat pembayaran atau tukar yang digunakan dalam transaksi keuangan e-commerce tersebut.

Dalam perekonomian modern, peranan uang bertambah sesuai dengan bertambah fungsinya. Uang tidak lagi hanya dikenal sebagai alat pertukaran, akan tetapi digunakan sebagai penghitung nilai (unit of accounts), alat penimbun kekayaan (store of value), dan standar pembayaran tundaan (standard of deferred payments), atau bahkan lebih ekstrim uang digunakan sebagai barang komoditi.

Perkembangan teknologi dan perekonomian mendukung perubahan sistem pembayaran yang baru yaitu uang digital. Di awali dengan sistem pembayaran dengan menggunakan logam berharga seperti emas dan perak, lalu berubah menjadi aset kertas seperti cek dan uang kertas. Selanjutnya, mengalami perubahan sebagai dampak dari pola hidup masyarakat di kota-kota besar, karena terhimpit dengan dengan waktu, kesibukan, dan karir sehingga membuat fenomena baru dengan memilih tranksaksi menggunakan uang elektronik.

Uang digital atau elektronik merupakan alat pembayaran atau tukar yang digunakan dalam transaksi keuangan ecommerce tersebut. Uang ini tidak dapat diraba karena bentuknya yang bersifat digital. Salah satu jenisnya adalah uang kripto (cryptocurrency). Munculnya ide penciptaan mata uang baru tersebut berbasiskan pada cryptography. Penggunaan lain dari cryptography dapat menunjang kehidupan masyarakat dalam bidang jual beli mata uang digital yang disebut dengan cryptocurrency. Cryptocurrency adalah mata uang digital yang tidak diberikan regulasi oleh pemerintah dan tidak termasuk mata uang resmi. Konsep inilah yang menjadi dasar dalam melahirkan mata uang digital yang saat ini kita kenal dengan istilah Bitcoin yang digunakan sebagai alat pembayaran layaknya mata uang pada umumnya.

Perkembangan transaksi digital seperti ini tentu tidak dapat dihindari oleh masyarakat, tapi juga mendapatkan respon yang berbedabeda tidak hanya di Indonesia tapi di negara lain. Hingga saat ini, hanya ada enam negara di dunia yang melegalkan transaksi Bitcoin yakni, Jepang, Amerika Serikat, Denmark, Korea Selatan, Finlandia dan Rusia.

Jenis cryptocurrency hingga saat ini sudah ada banyak jenisnya, diantaranya Bitcoin, Ethereum, XRP, Tether, Binance Coin, Cardano, dan lainnya. Jenis cryptocurrency paling umum dikenal oleh masyarakat secara global adalah Bitcoin. Bitcoin lebih dikenal dan mempunyai nilai yang cukup besar daripada jenis uang kripto lainnya. Dalam hal tersebut dapat dilihat pada gambar 1, menunjukan market cap Bitcoin berapada pada USD $731.46 \mathrm{~B}$, jauh lebih tinggi dibanding dengan Ethereum yang memiliki market cap USD 272.99.

Bitcoin merupakan salah satu dari beberapa mata uang digital yang pada awalnya muncul di tahun 2009 yang diperkenalkan oleh Satoshi Nakamoto sebagai mata uang digital yang berbasiskan cryptography. Bitcoin diciptakan oleh jaringan Bitcoin sesuai dengan kebutuhan dan permintaan Bitcoin, melalui sistematis berdasarkan perhitungan matematika secara pasti. Bitcoin juga merupakan pembayaran dengan teknologi peer-topeer dan open source. Setiap transaksinya akan disimpan dalam database jaringan Bitcoin serta terdesentralisasi atau tanpa otoritas pusat, lalu 
semua mekanismenya berjalan melalui sistem blockchain. Bitcoin digunakan atas dasar kebebasan dan idealisme bahwa pemerintah yang mengontrol hanya bekerja demi keuntungan subjektif yang korup dan berpihak kepada konglomerat belaka.

Kelebihan lain paling utama yang dimiliki Bitcoin adalah sistem Blokchain. Disamping itu, uang kripto ini memiliki kelemahan-kelemahan, diantaranya adalah tidak didasari pada aset (underlaying asset), belum adanya sistem kontrol dari lembaga yang bertanggung jawab sebagai otoritas, dan rawan untuk dijadikan sarana bentuk kejahatan, seperti pencucian uang karena tidak disertai nama jelas pemiliknya.

Secara legalitas, cryptocurrency sendiri banyak ditentang oleh instansi yang mempunyai otoritas di beberapa negara, seperti di negara Islandia, Bank Sentral Islandia menyatakan bahwa penggunaan mata uang kripto masih dianggap ilegal. Negara Rusia melalui Bank Sentral memperingatkan masyarakat yang menggunakan Bitcoin sebagai alat transaksi pembayaran berpotensi tindak kejatahan seperti tindakan terorisme dan pencucian uang. Di Indonesia sendiri, mata uang kripto belum mempunyai legalitas yang dikeluarkan oleh pemerintah, sehingga menjadi dinamika pro dan kontra (Azizah, 2020).

Badan Pengawas Perdagangan Berjangka Komoditi (BAPPEBTI) telah menerbitkan aturan resmi terkait kripto aset (cryptocurrency) sebagai komoditas dalam perdagangan berjangka komoditi (PBK) di Indonesia. Aturan ini dianggap telah memberikan angin segar dan peluang langkah awal kepada pasar keuangan digital. Pemerintah Indonesia melalui BAPPEBTI dan Peraturan Menteri Perdagangan (PERMENDAG) resmi mengatur kripto aset dapat dijadikan sebagai subyek Kontrak Berjangka, Kontrak Derivatif Syariah dan Kontrak Derivatif lainnya yang diperdagangkan di Bursa Berjangka Komoditi (CNN Indonesia, 2019).
Pro dan kontra terkait penggunaan mata uang Bitcoin sebagai alat transaksi pembayaran terjadi tidak hanya di Indonesia, tetapi juga di negara-negara lain. Hal ini dikarenakan Bitcoin belum memenuhi beberapa unsur dan kriteria sebagai mata uang yang berlaku di Indonesia. Bitcoin juga bukanlah mata uang yang dikeluarkan oleh negara, akan tetapi dikeluarkan melalui sistem cryptography jaringan-jaringan

komputer. Dari segi wujud, Bitcoin tidak berwujud koin, kertas, perak maupun emas.

Jika dilihat dari sudut pandang kelebihan dan kekurangan tentu Bitcoin memiliki keduanya jika digunakan sebagai mata uang, yaitu tidak adanya payung hukum yang mengatur peredaran mata uang Bitcoin. Selain itu tidak ada satu lembaga pun yang bertanggungjawab apabila terjadi penyalahgunaan terhadap Bitcoin misalnya pencurian, money laundry, penipuan, dan tindak pidana lainnya. Dari sisi kelebihannya, Bitcoin tidak mengenal batas negara, tidak terpengaruh karena kondisi politik di pemerintahan, berperan sebagai nilai lindung dari inflasi, dan sebagai salah satu bentuk baru tabungan masyarakat yang diterapkan dengan sistem yang tidak merepotkan karena peran bank sebagai perantara telah dihilangkan.

Penggunaan Bitcoin sebagai mata uang juga menjadi kajian yang menarik dari perspektif ekonomi Islam. Kemunculan fenomena baru dalam perekonomian tentu harus diikuti kesesuaiannya dengan hukum Islam. Penggunaan Bitcoin sebagai mata uang perlu diperhatikan apakah sudah tepat atau belum.

Dalam hadis dari Ubadah bin Shamit radhiyallahu 'anhu. Rasulullah shallallahu 'alaihi wa sallam bersabda: "Jika emas dibarter dengan emas, perak ditukar dengan perak, gandum bur (gandum halus) ditukar dengan gandum bur, gandum syair (kasar) ditukar dengan gandum syair, korma ditukar dengan korma, garam dibarter dengan garam, maka takarannya harus sama dan tunai. Jika benda yang dibarterkan berbeda maka takarannya 
boleh sesuka hati kalian asalkan tunai" (HR. Muslim 4147)

Dari hadis tersebut ditafsirkan mayoritas ulama menyepakati bahwa emas dan perak diberlakukan hukum riba karena memliki status sebagai alat tukar dan alat ukur nilai benda lainnya. Sehingga dalam kondisi tersebut bukan terfokus pada nilai instrinsik bendanya melainkan kegunaannya.

Tulisan ini akan membahas apa itu Cryptocurrency, Pro dan Kontra terhadap Cryptocurrency, apakah cryptocurrency dapat di jadikan sebagai mata uang atau aaset komoditas Bagaimana pendapat para ulama terhadap Cryptocurrency,. Maka penulis ingin menjelaskan bagaimana hukum cryptocurrency dalam persfektif Islam, halal atau haram dengan melakukan telaah literatur dengan pendekatan ushul fikih yang di lihat mulai dari al-quran, hadits, qiyas, dan maslahah almuarsalah, serta dilihat juga dari aspek maqashid syariah.

\section{TINJAUAN PUSTAKA}

\section{Pengertian Uang}

Dalam ilmu ekonomi, uang adalah suatu alat yang bisa diterima oleh masyarakat umum sebagai alat tukar-menukar ataupun alat pembayaran yang sah dalam suatu aktivitas ekonomi. Namun, sebagian lainnya ada yang mengatakan bahwa uang adalah suatu benda yang diterima oleh banyak masyarakat untuk bisa mengukur nilai, dijadikan sebagai alat tukar ataupun sebagai alat untuk melakukan kegiatan pembelian barang ataupun jasa yang mana bentuk kehadirannya sudah disetujui oleh peraturan tertentu.

Dalam suatu kegiatan ekonomi modern, selain dijadikan alat pembayaran dalam kegiatan jual beli, uang juga digunakan sebagai suatu alat untuk membayar utang. Namun, kebanyakan masyarakat masih belum banyak yang mengetahui perbedaan uang dan mata uang itu sendiri.
Menurut Bank Indonesia, dalam Undang-undang Nomor 7 Tahun 2011 Tentang Mata Uang, pengertian uang adalah alat pembayaran yang sah. Dalam buku Ekonomi Uang, Perbankan, dan Pasar Keuangan (2008) karya Frederic S Mishkin, secara ekonomi defenisi uang sebagai sesuatu yang secara umum diterima dalam pembayaran barang dan jasa atau pembayaran atas utang.

Menurut Veithal Rifaai (2001:1367) pengertian uang elektronik adalah alat pembayaran elektronik yang diperoleh dengan menyetorkan terlebih dahulu sejumlah uang kepada penerbit, baik secara langsung, maupun melalui agen-agen penerbit, atau dengan pendebitan rekening di bank, dan nilai uang tersebut dimasukan menjadi nilai uang dalam media uang elektronik, yang dinyatakan dalam satuan Rupiah, yang digunakan untuk melakukan transaksi pembayaran dengan cara mengurangi secara langsung nilai uang pada media uang elektronik tersebut.

$$
\text { Pengertian Uang Elektronik }
$$

(electronic money) menurut Peraturan Bank Indonesia No. 16/8/PBI/2014 adalah nilai uang yang disimpan secara elektronik pada suatu media server atau chip yang dapat dipindahkan untuk kepentingan transaksi pembayaran dan/atau transfer dana. Menurut Peraturan Bank Indonesia No.11/12/PBI/2009 Tanggal 13 April 2009 tentang Uang Elektronik (Electronic Money) dan juga perubahannya yaitu pada Peraturan Bank Indonesia Nomor. 16/8/PBI/2014, Uang Elektronik harus memenuhi unsur-unsur sebagai berikut, yaitu: (1) diterbitkan atas dasar nilai uang yang disetor terlebih dahulu oleh pemegang kepada penerbit; (2) nilai uang disimpan secara elektronik dalam suatu media seperti server atau chip; (3) digunakan sebagai alat pembayaran kepada pedagang yang bukan merupakan penerbit uang elektronik tersebut; (4) dan nilai uang elektronik yang disetor oleh pemegang dan dikelola oleh penerbit bukan merupakan simpanan sebagaimana dimaksud dalam undang-undang yang mengatur 
mengenai perbankan. Selain dari pada uang elektronik juga terdapat Alat Pembayaran dengan Menggunakan Kartu. Menurut Peraturan Bank Indonesia No. 14/2/PBI/2012, (APMK) terdiri dari Kartu Kredit, Kartu Debet dan/atau Kartu ATM. Peraturan Bank Indonesia ini membuat aturan dan definisi dari Uang Elektronik (emoney) berbeda dari pada Alat Pembayaran Menggunakan Kartu. Pada Peraturan Bank Indonesia No. 16/8/PBI/2014 ini juga menjelaskan bahwa berdasarkan pencatatan data identitas Pemegang, Uang Elektronik dapat dibedakan menjadi 2 (dua) jenis, yaitu (1) Uang Elektronik yang data identitas Pemegangnya terdaftar dan tercatat pada Penerbit (registered); dan (2) Uang Elektronik yang data identitas Pemegangnya tidak terdaftar dan tidak tercatat pada Penerbit (unregistered). Beberapa fasilitas yang diberikan oleh Penerbit jenis Uang Elektronik registered sebagaimana pada Peraturan Bank Indonesia ini, berupa (1) registrasi Pemegang; (2) Pengisisan Ulang (top up); (3) pembayaran transaksi; (4) pembayaran tagihan; (5) transfer dana; (6) Tarik Tunai; (7) penyaluran program bantuan pemerintah kepada masyarakat; dan/atau (8) fasilitas lain berdasarkan persetujuan Bank Indonesia. Sementara, fasilitas yang dapat diberikan oleh Penerbit jenis Uang Elektronik unregistered sebagaimana pada Peraturan Bank Indonesia ini, berupa (1) Pengisian Ulang (top up); (2) pembayaran transaksi; (3) pembayaran tagihan; dan/atau (4) fasilitas lain berdasarkan persetujuan Bank Indonesia.

Peraturan Bank Indonesia tentang Uang Elektronik ini juga menjelaskan mengenai biaya layanan fasilitas Uang Elektronik yang dibebankan kepada Pemegang. Biaya layanan yang dapat dikenakan oleh Penerbit kepada pemegang sebaimana terdapat dalam Peraturan Bank Indonesia ini berupa (1) biaya penggantian media Uang Elektronik untuk penggunaan pertama kali atau penggantian media Uang Elektronik yang rusak atau hilang; (2) biaya Pengisian Ulang (top up) melalui pihak lain yang bekerjasama dengan Penerbit atau menggunakan delivery channel pihak lain; (3) biaya Tarik Tunai melalui pihak lain yang bekerjasama dengan Penerbit atau menggunakan delivery channel pihak lain; dan/atau (4) biaya administrasi untuk Uang Elektronik yang tidak digunakan dalam jangka waktu terentu.

\section{Konsep Uang dalam Ekonomi Islam}

Pada dasarnya Islam memandang uang hanya sebagai alat tukar, bukan sebagai barang dagangan (komoditas). Oleh karena itu motif permintaan pada uang bertujuan memenuhi kebutuhan transaksi (money demand for transaction), bukan untuk spekulasi (Arifin, 2002). Islam juga sangat menganjurkan penggunaan uang dalam pertukaran, seperti dalam hadis yang diriwayatkan oleh Ata bin Yasar, Abu Said dan Abu Hurairah juga Abu Said al-Khudri menerangkan bahwa ternyata Rasulullah SAW tidak menyetujui transaksitransaksi dengan sistem barter, untuk itu dianjurkan sebaiknya menggunakan uang. Tampaknya beliau melarang pertukaran seperti ini karena ada unsur riba di dalamnya.

Dalam konsep Islam tidak dikenal money demand for speculation, karena spekulasi tidak diperbolehkan. Kebalikan dari sistem konvensional yang memberikan bunga atas harta, Islam menjadikan harta sebagai objek zakat. Uang adalah milik masyarakat sehingga dilarang menimbunnya di bawah bantal (tidak produktif), karena hal itu mengurangi jumlah uang yang beredar di masyarakat. Al-Qur'an dan hadis menjelaskan secara tekstual bahwa dinar dan dirham adalah mata uang yang digunakan sebagai alat tukar di zaman Nabi, ukuran nilai kekayaan yang disimpan, bukan sebagai komoditas. Dinar terbuat dari emas, sedangkan dirham terbuat dari perak. Namun di dalam al-Qur'an dan hadis tidak diperintahkan secara eksplisit menerapkan dinar dan dirham sebagai mata uang. Tertulis dalam firman Allah SWT dalam QS. at-Taubah [9]: 34: 


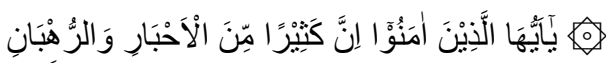

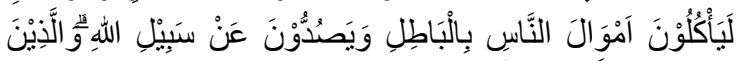

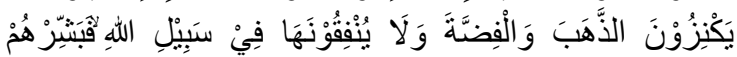

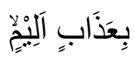

Artinya: Wahai orang-orang yang beriman, sesungguhnya banyak dari para rabi dan rahib benar-benar memakan harta manusia dengan batil serta memalingkan (manusia) dari jalan Allah. Orang-orang yang menyimpan emas dan perak, tetapi tidak menginfakkannya di jalan Allah, berikanlah kabar 'gembira' kepada mereka (bahwa mereka akan mendapat) azab yang pedih

Ayat ini menjelaskan tentang orangorang di zaman itu yang suka menimbun emas dan perak tanpa disedekahkan atau digunakan di jalan Allah SWT, maka sesungguhnya Allah akan memberikan adzab yang amat pedih di hari akhir. Dari penjelasan ayat ini dapat diambil kesimpulan bahwa emas dan perak merupakan harta yang dapat disimpan dan digunakan sebagai lambang kekayaan seseorang. Maka emas dan perak telah berfungsi sebagai alat tukar (medium of exchange), alat simpan nilai (store of value), satuan hitungan (unit of account) dan standar pembayaran masa datang (standard payment on future) (Karim, 2017).

Dalam sebuah hadis Nabi riwayat Muslim, Abu Sa'id al-Khudri dapat diketahui bahwa dalam Islam, koin dinar dan dirham (emas dan perak) bukanlah alat tukar satusatunya yang digunakan pada zaman dulu. Kurma, gandum dan garam juga difungsikan sebagai uang yang karenanya tidak ada hak istimewa yang mewajibkan hanya dinar dan dirham saja yang dijadikan mata uang. Alasan Nabi SAW memberikan kebebasan untuk memilih alat tukar ini, dikarenakan uang merupakan bagian dari kegiatan ekonomi yang disepakati suatu negara dan diatur secara umum dengan ketentuan yang sama (dalam Kusuma, 2020).

\section{Pengertian Cryptocurrency}

Cryptocurrency adalah mata uang digital di mana transaksinya dapat dilakukan dalam jaringan (online). Tidak seperti halnya mata uang kertas yang dicetak, cryptocurrency di desain dengan memecahkan soal-soal matematika berdasarkan kriptografi. Mata uang ini dibentuk berdasarkan teknologi Kriptografi agar tidak mudah digandakan atau berpindah terhadap pihak lain yang bukan pemiliknya dan tidak memiliki akses pada mata uang ini. Satoshi Nakamoto mengumumkan rilis pertama bitcoin, sistem uang elektronik baru yang menggunakan jaringan peer-to peer untuk mencegah pengeluaran ganda. Ini benar-benar terdesentralisasi tanpa server atau otoritas pusat.

Peer-to-peer, menghubungkan ke pengguna, membiarkan mereka untuk berbagi file dan sumber daya komputer tanpa server umum. Memfokuskan untuk membantu individu membuat informasi yang tersedia untuk penggunaan seseorang dengan menghubungkan para pemakai pada web. Contoh sintus P2P adalah Napster.com dan MyMp3.com. Teknologi kedua-duanya digunakan dengan mengizinkan konsumen untuk berbagi file dan jasa.

Kriptografi adalah sebuah cabang ilmu komputer yang mempelajari cara menyembunyikan informasi. Melalui Kriptografi, sebuah pesan rahasia diacak menjadi pesan yang seolah-olah tidak berbentuk, dan dikirimkan kepada pihak Muhamad Burhanudin. "Sejarah Penemuan Cryptocurrency".

Sementara itu hanya pihak yang dituju sajalah yang dapat mengartikan pesan acak tersebut dan mengubahnya kembali menjadi pesan rahasia dari sang pengirim. Sejarah Kriptografi dimulai pada zaman Romawi kuno, ketika Julius Caesar berniat mengirimkan pesan pada salah satu jendral di medan perang, kemudian pesan itu ia harus kirimkan melalui kurir, namun ia tidak ingin jika pesan tersebut dibuka oleh kurir sebelum diterima oleh sang jenderal. Maka ia mengirimkan pesan tersebut dengan mengacak huruf dalam pesan. 


\section{METODE PENELITIAN}

Penelitian ini merupakan jenis penelitian kualitatif yang merupakan penelitian deskriptif. Tujuan dari penelitian kualitaitf ini untuk menguraikan dan menganalisis peristiwa, dinamika sosial, fenomena dan sikap persepsi individu maupun kelompok terhadap sesuatu. Pendekatan penelitian ini menggunakan pendekatan normatif syar'i, yaitu melakukan penelitian dengan penelaahan kajian studi syariat Islam dengan studi telaah literatur yang di lihat mulai dari al-quran, hadits, qiyas, dan maslahah al-muarsalah, serta dilihat juga dari aspek maqashid syariah. Tujuan pendekatan ini adalah mengetahui kesimpulan dari aspek-aspek yang diteliti merujuk pada hukum Islam. Pendekatan normatif syar'i pada penelitian ini adalah menggunakan pendekatan ushul fiqih sebagai metode istinbath dalam penetapan hukum cryptocurrency sebagai alat transaksi.

\section{HASIL DAN PEMBAHASAN}

\section{Analisis Persfektif Islam Terhadap Cryptocurrency}

Penggunaan uang (fiat rupiah) digital dapat direfleksikan kali ini untuk mata uang kripto dan pemenuhan kriteria sebagai mata uang dan/atau alat pembayaran yang sah. Jenis cryptocurrency yang paling terkenal saat ini adalah bitcoin. Secara umum, para ulama dan pakar syariah memiliki dua pendapat berbeda. Pertama, beberapa ulama berpendapat bahwa cryptocurrency adalah haram, artinya dilarang oleh syariah. Kelompok lain berpandangan bahwa cryptocurrency pada prinsipnya halal, artinya diizinkan. Mufti Besar Mesir Shaykh Shawki Allam pada 2018 telah menyatakan bahwa bitcoin dan cryptocurrency adalah haram. Syaikh mengutip alasan-alasan utama ini dalam pernyataannya antara lain; Bitcoin mudah digunakan untuk kegiatan ilegal; Bitcoin tidak berwujud dan memungkinkan untuk pencucian uang dan penipuan.
Otoritas keagamaan pemerintah Turki juga menyatakan bahwa bitcoin dilarang, karena terbuka untuk spekulasi (gharâr dan maysîr) berlebihan (Abu Bakar, 2018). Pusat Fatwa Palestina (Fatwa Center of Palestine) juga mengeluarkan fatwa haram terkait bitcoin dan cryptocurrency, dengan alasan penerbit bitcoin tidak diketahui dan termasuk perjudian. Cendikiawan Muslim yang berbasis di Inggris Shaykh Haitam, menulis makalah dalam bahasa Arab. Ia menyatakan bahwa bitcoin dan cryptocurrency lainnya dilarang dan tidak kompatibel dengan syariah.

Abdullah bin Muhammad bin Abdul Wahab Al'Aqil, seorang doktor Fakultas Syari'ah di Universitas Islam Madinah, Arab Saudi, menyatakan pelarangan bitcoin karena mengandung unsur riba yang besar (Abdullah, 2017). Ulama Saudi Arabia Syekh Assim alHakeem memberi fatwa bahwa mata uang digital bitcoin dilarang dalam hukum Islam. Ia menyatakan bahwa bitcoin adalah gerbang terbuka untuk pencucian uang, jual beli obatobatan terlarang dan penyelundupan (https://bitcointalk.org, 2019). Dewan Hukum Personal Muslim India (AIMPLB) menyebut bitcoin sebagai hal yang tidak islami. Oleh sebab itu, Lembaga Muslim tersebut meminta masyarakat untuk menghindari penggunaan mata uang kripto tersebut. Pakar-pakar dan sebagian ulama lain berpandangan bahwa bitcoin dibolehkan pada prinsipnya.

Pandangan ini dapat dianalisis berdasarkan pemaparan sebelumnya sehubungan dengan kriteria dan definisi uang dan jual beli. Kaidah fikih masyhûr yang dijelaskan oleh para ahli hukum, yakni: "alAshlu fî̀ al-Mu'âmalât al-'Ibâh\}ah, Illâ an Yadulla al-Dalîl 'ala Tah\}rîmihâ." Ini berarti bahwa aturan asalnya diperbolehkan dalam transaksi keuangan dan bisnis. Dengan kata lain, semuanya diizinkan kecuali ditemukan dalil yang itu jelas bertentangan dengan prinsip-prinsip syariah.

Beberapa qaul masyhûr lain dalam etika ekonomi Islam, yakni ungkapan yang singkat dari Ibnu Taimiyah: "al-Ashlu fî al- 
'Uqûd Ridha al-'Aqidain" yang bermakna bahwa dasar dari akad adalah keridhaan kedua belah pihak. Dalam kitab I'lâm al-Muwaqqîn, Ibnul Qayyim berkata bahwa "sesungguhnya fatwa bisa berubah mengikuti perubahan zaman, tempat, adat istiadat dan kondisi. Dan semua itu berasal dari Allah. Wabillahittaufiq (dalam Kusuma, 2020).

Selanjutnya Muhammad Mushthafa alZuhaily dalam kitab al-Qawaid alFikhiyyah menjelaskan kaidah yang maknanya: "Terkadang sejumlah hukum syariat berlandaskan kepada kebiasaan manusia dan adat istiadatnya. Maka apabila telah berubah adat tersebut dari adat pada zaman sebelumnya, berubah pula teknis dan hukumnya, sedangkan hukum-hukum syariat yang asalnya bukan berdasarkan adat dan kebiasaan manusia tidak berubah (dalam Kusuma, 2020). Berdasar pada dalil di atas, segala mata uang digital/virtual ataupun kripto yang telah memenuhi persyaratannya, dapat diterima sebagai uang. Pusat Fatwa Seminar Islam Afrika Selatan, Dâr al-'Ulûm Zakariyya, telah mengambil posisi bahwa bitcoin memenuhi persyaratan sebagai uang, oleh sebab itu bitcoin diperbolehkan untuk berdagang.

Namun, mereka mencatat bahwa untuk dikualifikasikan sebagai mata uang, harus disetujui oleh otoritas pemerintah terkait (kumparan.com , 2019). Transaksi bitcoin juga telah dibuka di beberapa Negara Muslim. Negara pertama di Timur Tengah yang membuka adalah Uni Emirat Arab (UEA) dengan BitOasis: mata uang kripto baru, yang dikonversi dengan emas. Perbankan syariah tersebut menuntut aktivitas perbankan agar selalu mengikuti hukum Islam.

The Shariah Review Bureau (SRB), sebuah firma penasihat Islam yang dilisensikan oleh bank sentral Bahrain, memberikan sertifikasi untuk Stellar: sebuah penyedia platform blockchain asal California, AS. Sertifikasi halal ini tidak hanya untuk sistem blockchain dari Stellar, akan tetapi bagi mata uang kripto mereka juga, yaitu Lumens
(XLM), nilai kapitalisasi Lumens dihargai 5 Milyar USD atau sekitar 75 Triliiun dan bisa ditaksir lebih tinggi (www.cnbcindonesia.com/syaria, 2019).

Di Malaysia, HelloGold meluncurkan GOLDX sebagai cryptocurrency yang didukung berdasarkan pada harga emas dan telah mendapat persetujuan dari para Otoritas Ulama Islam di Amanie Advisors yang berbasis di Kuala Lumpur. Transaksi koin islami ini terjadi dalam periode yang ditentukan dan menjadikannya less volatile (fluktuasi harga tidak terlalu ekstrim) serta dapat mengatasi masalah ambiguitas penetapan harga (www.aljazeera.com, 2018).

\section{Analisis cryptocurrency Sebagai Mata Uang}

Di Indonesia, penggunaan mata uang kripto sebagai alat pembayaran dalam negeri dianggap tidak sah. Undang-Undang No. 7 tahun 2011 tentang Mata Uang pada Pasal 1 Ayat 1 dijelaskan bahwa alat pembayaran yang diterima dan dianggap sah di Indonesia hanya mata uang Rupiah. Larangan tersebut juga dipertegas melalui PBI (Peraturan Bank Indonesia No. 18/40/PBI/2016 tentang Penyelenggaraan Pemrosesan Transaksi Pembayaran. Namun demikian, keberadaan cryptocurrency di Indonesia bukan barang yang ilegal, Pemerintah melalui Bank Indonesia mempersilahkan penggunaan cryptocurrency untuk disimpan atau dijual belikan sebagai aset dengan risiko ditanggung masing-masingDalam meenentukan ataupun menetapkan hukum cryprocurrency, Islam mempunyai metode dan sumber rujukannya sendiri, baik dari sumber primer yaitu al-Quran dan al-Hadits, kedua sumber tersebut dianalisis sebagai rujukan dalam menetapkan hukum oleh para mujtahid, selain itu para mujtahid juga mgenal metode lain dalam menetapkan hukum, seperti qiyas, maslahah mursalah adzariah dan lainnya. Metode dalam menetapkan hukum syar'i tersebut dikenal sebagai ilmu ushul fiqih. 
Al-quran dalam surat an-Nisa ayat 29, yang merepresentasikan tentang kegiatan atau aktivitas ekonomi secara umum, termasuk dalam cryptocurrency yang berbunyi:

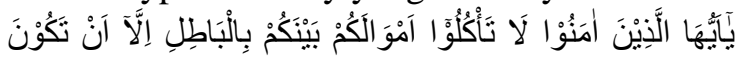

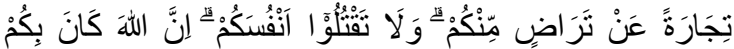
رَحِيْمَا.

Artinya: Wahai orang-orang yang beriman! Janganlah kamu saling memakan harta sesamamu dengan jalan yang batil (tidak benar), kecuali dalam perdagangan yang berlaku atas dasar suka sama suka di antara kamu. Dan janganlah kamu membunuh dirimu. Sungguh, Allah Maha Penyayang kepadamu. (QS. An-Nisa 4: 29)

Ayat diatas menjelaskan terkait setiap aktivitas transaksi harus terhidar dari batil. Kata batil sendiri mempunyai makna yang luas dalam memahaminya, seperti setiap transaksi yang dilakukan harus sesuai dengan nilai-nilai ajaran Islam, atau tidak melanggar ajaran islam. Kata batil sendiri memiliki makna fasad yang berarti rusak, sia-sia, tidak berguna dan palsu, yang berasal dari asal kata bathalayabthulu-bathlan.

Secara terminology batil diartikan sebagai antonim dari sesuatu yang haqq (kebenaran), yaitu sesuatu yang tidak memiliki manfaat yang baik (sia-sia) baik di dunia atau di akhirat (Al-Asfahani, 2012). Dalam Tafsir al-Munir cara batil adalah cara yang diharamkan dalam syariat islam, seperti transaksi ribawi, maysir (unsur judi), gharar dan lain sebagainya. Konsekuensi dari batil sendiri adalah akad tersebut rusak dan batal (Zuhaly, 1998). Kaitannya dalam penggunaan mata uang kripto, saat ini para pengguna mata uang kripto lebih banyak menggunakannya untuk alat berspekulasi dan trading. Hal tersebut bertujuan untuk meraih keuntungan aktivitas investasi dan trading dengan spekulasi.

Selanjutnya, aktivitas investasi dengan spekulasi ini dalam islam mengandung unsur gharar, maysir dan riba seperti di jelaskan dalam Al- Quran surat al-Maidah ayat 50 yang artinya: Wahai orang-orang yang beriman! Sesungguhnya minuman keras, berjudi, (berkurban untuk) berhala, dan mengundi nasib dengan anak panah, adalah perbuatan keji dan termasuk perbuatan setan. Maka jauhilah (perbuatan-perbuatan) itu agar kamu beruntung.

Mata uang kripto saat ini masih mengandung voltalitas harga tinggi, dan ketidak stabilan hingga fluktuasi nilai yang sangat tinggi, hal ini identik dengan spekulasi pada selisih harga. Sehingga timbulnya niat mendapatkan hasil atau keuntungan dari selisih harga tersebut tergolong dalam unsur gharar dan maysir jika digunakan untuk investasi dan trading cryprto currency.

Dalam Hadits Konsep mata uang kripto sebagai alat transaksi jual beli dapat ditinjau pada hadits Ubadah bin Shamit r.a.:

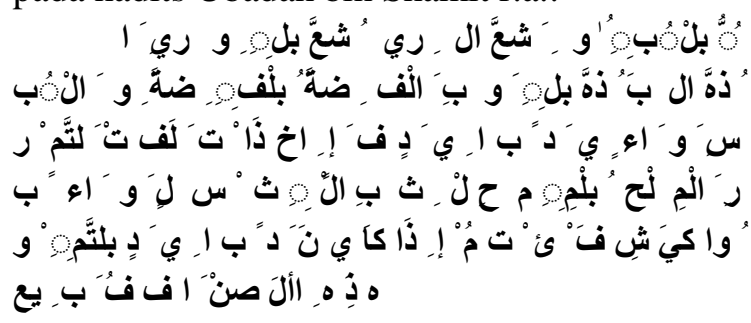

"Jika emas dijual dengan emas, perak dijual dengan perak, gandum dijual dengan gandum, sya'ir (salah satu jenis gandum) dijual dengan sya'ir, kurma dijual dengan kurma, dan garam dijual dengan garam, maka jumlah (takaran atau timbangan) harus sama dan dibayar kontan (tunai). Jika jenis barang tadi berbeda, maka silakan engkau membarterkannya sesukamu, namun harus dilakukan secara kontan (tunai)." (HR. Muslim no. 1587).

Pada hadits tersebut terdapat dua kata kunci dalam melakukan transaksi, yaitu pertukaran yang dilakukan harus sama nilai atau takarannya dan transaksi tersebut harus dilakukan secara tunai. Mata uang kripto dianalogikan pada pertukaran emas dengan emas dan perak dengan perak. Pertukaran mata uang kripto dapat ditukarkan dengan mata uang lain seperti dolar dan rupiah, dalam ilmu fiqih pertukaran mata uang ini disebut dengan sharf.

Imam Ibn Taymiyah dalam Majmu' Fatawa menerangkan bahwa uang merupakan 
suatu benda yang telah disepakati para pengguna untuk dijadikan alat tukar, walaupun dari sebongkah batu atau sepotong kayu. Artinya, penggunaan mata uang kripto hingga titik ini dibolehkan, akan tetapi imam AlGazali mensyaratkan penggunaan mata uang harus dikeluarkan dan diedarkan oleh otoritas dari pemerintahan serta pemerintah telah menyatakan uang tersebut adalah alat transaksi pembayaran yang sah dan resmi (Mansur, 2009).

Cryptocurrency masih menjadi perdebatan dalam penggunaannya di berbagai negara, Indonesia sendiri belum atau bahkan melarang penggunaan mata uang kripto tersebut sebagai alat transaksi pembayaran yang sah. Sehingga dalam hal ini, penggunaan mata uang kripto sebagai mata uang dan alat transaksi pembayaran tidak diperbolehkan dalam sudut pandang syariah, karena agama Islam sendiri menekankan untuk mematuhi perintah atau aturan dari ulil amri, dalam hal ini adalah pemerintah.

Namun kemudian, mata uang kripto ini belum mempunyai kejelasan dan tidak dapat terlihat berbentuk fisiknya, serta belum ada kepastian hukum secara legalitas baik di Indonesia sendiri atau kesepakatan global, oleh karenanya hal tersebut masih dapat disebut abu-abu dan gharar, terlebih penggunaannya dalam investasi dan trading, yang menjadikan mata uang kripto ini tidak lepas dari spekulasi harga yang sangat fluktuatif dan penggunannya hanya sebagai alat untung dan rugi, maka mengandung unsur maysir. Maka Rasulullah juga melarang transaksi yang mengandung unsur gharar dan maysir hadits nabi saw. yang diriwayatkan abu Hurairah:

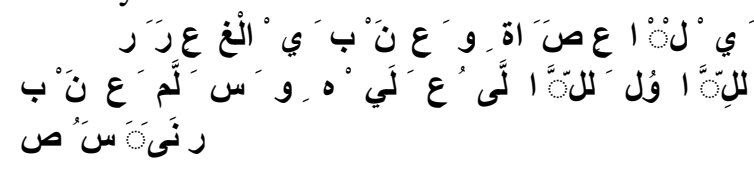

"Rasulullah Shallallahu 'alaihi wa sallam melarang jual beli al-hashah dan jual beli gharar" (HR. Muslim: 1513)

Kemudian masalah cryptocurrency ini juga dapat di qiyaskan yang merupakan salah satu metode ijtihad dalam penetapan hukum terkait dengan syariat Islam. Qias memiliki arti taqdiru assyay'i bi ghairihi yang berarti mengukur suatu benda dengan sesuatu yang universal dan memiliki karakteristik yang sesuai dengan benda tersebut (Hasan, 2001). Dalam penetapan hukum cryptocurrency, dapat diqiyaskan dengan hadits Imam Malik, yaitu:

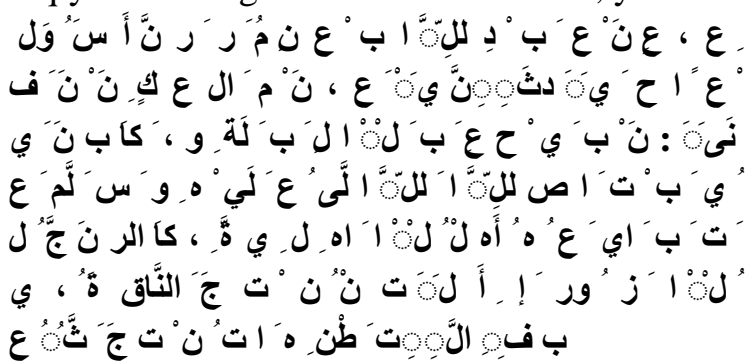

"Yahya bercerita kepadaku, dari Malik, dari Nafi', dari Abdullah ibn Umar bahwa Rasulullah shallallahu 'alaihi wasallam melarang jual beli hablu al-hablah. Jual beli ini merupakan praktik jual-beli masyarakat Jahiliyah, dimana seseorang menjual unta yang akan dilahirkan oleh janin, namun janin itu masih ada dalam perut induknya" (alMuwatha, 1359).

Hadits diatas menjelaskan larangan jual beli hablu al-habla, adalah menjual janin unta yang masih dalam kandungan induknya. Larangan jual beli ini dikarenakan jahalah (tidak diketahui) sifat dan karakternya. Unsur jahalah tersebut mengakibatkan timbulnya unsur gharar dan mysir yang berakibat pada spekualitf (untung-untungan). Transaksi cryptocurrency dapat dianalogikan dengan transaksi hablu al-habla dengan ashl-nya jual beli hablu al-habla. Far'un-nya yaitu jual beli mata uang kripto. Hukmul alshl-nya adalah haram jual-beli hablu al-habla. Illat atau motif hukumnya adalah mempunyai kesamaan akan transaski yang tidak jelas (jahalah), baik dari sisi kuantitas atau kualitasnya.

Mata uang kripto dari awal kemunculannya hingga sekarang, masih menjadi perhatian di kalangan masyarakat di berbagai dunia, pro maupun kontra terkait legalitas penggunaanya, baik dari hukum positif hingga dalam pandangan syariah Islam menjadi fenomena tersendiri. Voltase fluktuatif harga dan ketidakpastian dari mata uang ini 
yang menjadikan perdebatan. Pada dasarnya, syariah Islam memandang bahwa segala sesuatu adalah boleh dalam aspek muamalah, hingga terdapat dalil-dalil yang melarangnya.

Sebagaimana yang telah dijelaskan bahwa nilai mata uang kripto sendiri yang perubahanya sangat cepat dan fluktuasi yang tinggi, sehingga berdampak pada kekhawatiran akan terjadinya bubble economic dikarenakan spekulasi para penggunanya, disamping itu mata uang kripto mengandung unsur jahalah (ketidak jelasan) dan digunakan sebagai trading yang memuat unsur maysir dan jatuh pada praktik ribawi, dimana para trader membeli saat harga rendah dengan harapan dapat dijual disaat harga naik tinggi.

Dapat dikatakan mata uang kripto ini hanya digunakan sebgai alat spekulasi, bukan murni investasi. Beberapa aspek kemafsadatan dari penggunaan mata uang kripto ini antara lain rentan terhadap risiko penggelembungan ekonomi (bubble economic), sehingga berdampak merugikan masyarakat luas. Selain itu mata uang kripto tidak diterbitkan oleh otoritas pemerintahan pusat, dan tidak ada pengawasan atau monitoring dari pemerintah pusat, sehingga dapat memunculkan kemudharatan yang besar, baik untuk pencucuian uang, tindak pidana teroris dan lain sebagainya. Dengan demikian, pengguanaan mata uang kripto ini mengandung sesuatu yang akan berdampak mada kemafsadatan yang lebih bukan mewujudkan kemaslahatan.

Merujuk paparan pandangan terhadap diharamkannya bitcoin di atas, peneliti dapat menyimpulkan bahwa kebanyakan ulama (Jumhûr) dan otoritas negara sepakat akan tidak diperbolehkannya (haram) bitcoin dalam fungsinya sebagai alat pengganti uang sah. Mereka memiliki pandangan yang sama bahwa bitcoin terlalu banyak spekulasi, tidak berwujud, tidak adanya regulasi pemerintah yang resmi (payung hukum) dan dapat dengan mudah digunakan untuk kegiatan ilegal. Bersandar dari alasan negara-negara yang membolehkan dan otoritas Islam yang menghalalkan uang kripto, terlepas dari bitcoin yang memiliki beberapa keunggulan dan sisi positif seperti pengendalian inflasi, keamanan, efisiensi transaksi dan desentralisasi.

Peneliti dapat menyimpulkan bahwa mata uang kripto yang dibolehkan ialah mata uang yang diterbitkan atau disahkan oleh negara masing-masing, bukan bitcoin. Dikarenakan adanya perlindungan penetapan harga dan ketentuan yang berpatokan pada nilai intrinsik dari emas atau dari mata uang negara tersebut.

\section{Analiss Cryptocurrency sebagai Aset Komoditas}

Pemerintah Indonesia telah meresmikan penggunaan mata uang kripto sebagai komoditas dalam Perdagangan Berjangka. Namun hingga saat ini belum mengeluarkan peraturan/ketentuan resmi tentang pelarangan ataupun sanksi kepada masyarakat yang masih melakukan transaksi jual beli online menggunakan bitcoin.

Komoditi dapat diartikan dalam beberapa definisi, di antaranya; pertama, suatu barang atau benda nyata yang dapat diperdagangkan dengan relatif mudah, dapat diserahkan wujudnya, dapat ditukarkan dengan produk lain dengan jenis yang sama dan dapat disimpan untuk jangka waktu tertentu, yang biasanya dapat dijual atau dibeli oleh investor melalui bursa berjangka. Kedua, secara umum, komoditi adalah suatu produk yang dapat diperdagangkan termasuk di dalamnya mata uang asing (valas), indeks dan instrumen keuangan. Komoditi memiliki karakteristik harga yang ditentukan dari permintaan dan penawaran pasar, bukan berdasarkan hitungan penyalur atau penjual. Kemudian harga tersebut disimpulkan berdasarkan perhitungan harga masing-masing (daya beli) pelaku komoditi. Contoh dari subjek komoditas yakni produk pertanian, seperti; kakao, gula, beras, crude palm oil CPO, jagung dan lainnya. Dalam hal hasil bumi atau pertambangan terdapat batu bara, mineral dan emas yang diperdagangkan juga sebagai komoditas (Nurlaila, 2014). 
Perdagangan Berjangka Komoditi meliputi beberapa jenis. Pasar berjangka komoditi dibedakan menjadi dua macam yaitu Over the Counter (OTC) dan Bursa berjangka. OTC merupakan pasar berjangka kontrak bilateral. Sedangkan bursa berjangka merupakan pasar berjangka sistem kontrak multilateral. OTC komoditas sering juga disebut dengan Commodity Market. Sedangkan bursa berjangka sering disebut Commodity Exchange (Samsul, 2010). Dari Commodity Market tersebut dibagi lagi menjadi beberapa jenis kontrak, yaitu Kontrak Forward dan Swap. Commodity Exchange (bursa berjangka) menurut Undang-undang Nomor 10 Tahun 2011 Tentang Perdagangan berjangka Komoditi memiliki empat jenis kontrak yaitu Kontrak Futures, Kontrak Derivatif, Kontrak Derivatif Syariah dan Kontrak Option.

Sesuai kaidah fikih yang menyatakan bahwa pemerintah wajib melindungi dan mengatur segala hal yang berkaitan tentang kehidupan masyarakatnya dan agar selalu mendahulukan maslahat dan manfaat untuk rakyat secara keseluruhan. "Tasharruf al-Imâm 'ala al-Ra'iyyah Manûthun bi al-Mashlahah (Al-Suyuti , 1983). Ketentuan standar minimal modal/aset pihak pengelola atau Penyedia aset kripto yang dalam hal ini bitcoin, merupakan usaha pemerintah Indonesia dalam menjaga likuiditas pihak pengelola, sehingga selalu berada di jalur hijau atau bisa dikatakan terkendali/ aman. Bila terjadi perselisihan atau tindak kriminal yang melanggar peraturannya, dapat diselesaikan secara mufakat ataupun hukum pada Badan Arbitrase Perdagangan Berjangka Komoditi (BAKTI) atau Pengadilan Negeri (PN) di Indonesia. Menurut paparan beberapa pandangan ulama sebelumnya,Crytocurrency atau bitcoin juga memiliki sisi negatif dalam kedudukannya sendiri sebagai mata uang, sebagai alat tukar atau alat pembayaran maupun sebagai komoditas dalam perdagangan berjangka.

Berdasarkan kaidah usul fikih yang berbunyi: "Dar'u al-Mafâsid Muqaddam 'ala
Jalbi al-Mashâlih." (Pusat Pengkajian dan Pengembangan Ekonomi Islam, 2009). Kaidah ini bermakna lebih baik/utama menghindari mafsadah (kejelekan/kerusakan) daripada mengambil kemaslahatannya. Ini menyiratkan bahwasanya dalam perdagangan komoditi di Indonesia bitcoin masih tidak dapat terhindar dari beberapa sifat yang dilarang dalam jual beli menurut syariat Islam, salah satunya ialah spekulasi.

Bitcoin rentan digunakan membantu kemaksiatan. Pencucian uang, penggelapan dana dan kegiatan ilegal lain merupakan unsur yang sulit dihindarkan dalam penggunaan komoditas bitcoin. Uang yang digunakan untuk investasi aset bitcoin, berasal dari uang haram yang sengaja dihilangkan dengan niat agar tidak terlacak oleh otoritas setempat. Mayoritas ulama sepakat akan diharamkannya bila terbukti mengantarkan kepada perbuatan maksiat (dalam Kusuma, 2020).

Terdapat (potensi) unsur riba. Dikarenakan sifat bitcoin yang sangat fluktuatif setiap harinya, maka konsumen/pemilik bitcoin lebih suka membeli bitcoin disaat harganya turun, lalu menjualnya dengan segera disaat harganya naik, ini ditakutkan penurunan harga keesokan harinya. Tingkat maysîr/gambling perdagangan komoditi bitcoin terbilang tinggi, mengingat dalam waktu dekat bitcoin akan segera habis. Seluruh transaksi yang mengandung unsur perjudian (maysîr), ketidakjelasan (gharâr), penipuan (tadlîs) dan rasuah adalah batil, terlarang dan harâm lighairihi hukumnya. Mata uang virtual ini dinilai masih terdapat unsur maysîr di dalamnya, karena bisnis bitcoin ini seperti bertaruh.

Dengan demikian, dapat di katakan bahwa penggunaan uang virtual bitcoin sebagai komoditas dalam kontrak derivatif syariah adalah harâm lighairihi atau haram karena ada factor-faktor lain di luar zat. Crytocurrency atau Bitcoin dalam kedudukannya sebagai komoditas di PBK masih mengandung unsur maysîr karena di dalamnya terdapat spekulasi tinggi dan bersifat 
untung-untungan. Hal itu lebih berat daripada perdagangan valuta asing (valas). Maka penggunaan bitcoin sebagai instrumen dalam kontrak derivatif syariah adalah harâm lighairihi, atau haram karena faktor luar (spekulasi/maysîr, riba, rentan praktek ilegal: money laundry).

\section{KESIMPULAN DAN SARAN}

Keberadaan cryptocurrency sebagai inovasi dan perkembangan teknologi yang menggunakan sistem blockchain memberikan banyak dampak positif seperti kemudahan dan kecepatan dalam melakukan transaksi, lebih murah dan lebih terjaga kerahasiannya serta dapat digunakan dalam lintas negara dan lintas benua.

Ajaran agama Islam dalam bahasan aspek muamalah mengenal kaidah fiqih "pada dasarnya setiap aktivitas muamalah itu dibolehkan sampai ada dalil yang melarangnya". Pada dasarnya eksistensi cryptocurrency sebagai mata uang virtual itu dibolehkan, karena sudah diakui oleh berbagai masyarakat, namun demikian harus dilihat legalitas dan pengakuan oleh pemerintah sebagai hak dan kewajiban pemerintah. Termasuk dalam penerbitan mata uang tersebut, hal ini untuk menghindari kemungkinan kemafsadatan yang dapat terjadi. Pada praktiknya, saat ini transaksi cryptocurrency lebih banyak digunakan sebagai spekulasi yang mengakibatkan unsur gharar dan maysir yang termasuk dalam bentuk batil atau unsur yang dilarang dalam prinsip ajaran Islam. Transaksi mata uang kripto diqiyaskan pada jual beli (hablu al habla) jual beli janin unta dalam kandungan

Penggunaan cryptocurrency sebagai instrument investasi mengandung spekulasi tinggi yang bersifat untung-untungan. Penggunaan mata uang kripto juga dapat dilihat dengan motode sad adzariah, dengan ketidak jelasan dan mengandung unsur gharar dan maysir, terlebih tidak jelasnya legalitas dari pemerintah terkati dengan penggunaan cryptocurrency ini, maka akan menimbulkan dampak negative yang lebih besar seperti penyelewengan dan penggunaan dana untuk kejahatan seperti terorisme dan pencucian uang. Oleh karena itu pencegahan kemudharatan atau kemafsadatan lebih diutamakan dibanding dengan kebermanfaatannya.

Penulis menyimpulkan bahwasanya secara teknis dan praktek, crytocurrency tidak bisa dinyatakan sebagai mata uang, sedangkan cryptocurrency dapat dinyatakan aset komoditas jika, mengandung nilai manfaat dan memiliki underlying asset. Jika syarat tersebut tidak terpenuhi maka haram hukumnya.

\section{REFERENSI}

Abdullah, Hukum-Hukum Fikih yang berkenaan dengan Mata Uang Digital Bitcoin, (Karya Ilmiah Doktoral Fakultas Syari'ah: Universitas Islam Madinah, Arab Saudi, 2017), 53.

Adiwarman A Karim, Bank Islam-Analisis Fiqih dan Keuangan, Edisi Ketiga, (Jakarta: PT Raja Grafindo Persada, 2007), 117.

Al-Suyuti, Al-Ashbah wa al-Nadzhair fî Qaw \} â'id wa Furu'i Fiqh al-Syafi'iyyah, (Beirut: Dâr el-Kutub al-Alamiyah, 1983), 178.

Al-Mausû'ah al-Fiqhiyyah li Jama'ah min al'Ulamâ, Jil. 11, (Kuwait: Departemen Kementrian Wakaf Kuwait).

Al-Suyuti, Al-Ashbah\} wa al-Nadzhair fî Qawâ'id wa Furû'i Fiqh alSyafi'iyyah, (Beirut: Dâr el-Kutub Al-Alamiyah, 1983).

Annisa Rahma Diasti, Skripsi Starta-1 Departemen Hukum Dagang, (Yogyakarta: Fakultas Hukum, Universitas Gadjah Mada, 2017).

Asep Ausop, “Teknologi Cryptocurrency Bitcoin Untuk Investasi Dan Transaksi Bisnis Menurut Syariat Islam," dalam Jurnal Ilmiah, Kelompok Keahlian Ilmu Kemanusiaan, (Bandung; 
Fakultas Seni Rupa dan Desain Institut Teknologi Bandung, 2018).

Brian Kelly, The Bitcoin Big Bang: How Alternative Currencies are About to Change the World, (Jakarta: PT Elex Media Komputindo, 2018).

Fatwa Dewan Syariah Nasional-Majelis Ulama Indonesia No:82/DSNMUI/VII/2011, Tentang Perdagangan Komoditi Berdasarkan Prinsip Syariah di Bursa Komoditi. Ibnu Manzhur, Lisân alArab, Juz 3, (Beirut: Dâr al-Shadr, 1999).

Ibnu Qudamah, Al-Mughni, , Jil. 6, (Kairo: Dâr al-Hadîts, 2004). Ibrahim Nubika, Bitcoin: Mengenal Cara Baru Investasi Generasi Millenial, (Yogyakarta: Genesis Learning, 2018).

https://bitcointalk.org/index.php?topic $=489511$ 4.0, diakses pada 3 November 2019.

https://kumparan.com/kumparantech/hasilstudi-ini-sebut-bitcoin-halalsesuaisyariah-islam, diakses 28 November 2019.

https://www.cnbcindonesia.com/syariah/20180 718151108-29-24182/matauangdigital-ini-dapat-sertifikasi-halaldari-bahrain, diakses pada 11 November 2019.

https://www.aljazeera.com/news/2018/ 04/islam-cryptocurrency-halalhalal180408145004684.html, diakses 30 November 2019.

https://bitcointalk.org/index.php?topic $=489511$ 4.0, diakses pada 3 November 2019. https://kumparan.com/kumparantech/h asil-studi-ini-sebut-bitcoinhalal-sesuaisyariah-islam, diakses 28 November 2019.

https://www.cnnindonesia.com/ekonomi/20190 215184351-78-369717/ aturanbappebti-soal-Bitcoin-dinilai-berikepastian-pasar, diakses pada 19 September 2019.

M., M Abu Bakar, "Shariah Analysis of Bitcoin, Cryptocurrency and
Blockchain," dalam Paper Blossom Finance, Blossom Labs, Vol 1.2.0 (2018), 5-21.

Nurlaila, "Bursa Komoditi Dalam Perspektif Hukum Islam", Skripsi, (Fakultas Syariah dan Hukum, UIN Syarif Hidayatullah, 2014), 55-64. Cryptocurrency dalam Perdagangan Berjangka Komoditi di Indonesia 117 Volume 16, Number 1, May.

Samsul, Mohammad, Pasar Berjangka Komoditas dan Derivatif, (Jakarta: Salemba Empat, 2010), 84.20

Soewardi Yusuf, Commodity Trading Sebagai Alternatif Instrument Solusi Likuiditas pada Perbankan Syariah, (Jakarta: Karim review, special edition January, 2008), 6.

Pusat Pengkajian dan Pengembangan Ekonomi Islam (P3EI) UII Yogyakarta, Ekonomi Islam, (Jakarta: PT. Raja Grafindo Persada, 2009), 133.

Zainul Arifin, Dasar-Dasar Manajemen Bank Syariah, (Jakarta: AlvaBet, 2002).

Steven D Brown, "Cryptocurrency and criminality: The Bitcoin opportunity, SAGE," dalam The Police Journal: Theory, Practice and Principles, Vol. 89, (2016), 327-339. Cryptocurrency dalam Perdagangan Berjangka Komoditi di Indonesia... 123 Volume 16, Number 1, May 2020

Teddy Kusuma Journal TSAQAFAH PT. Bursa Komoditi dan Derivatif Indonesia, Sekilas Mengenai ICDX: Peluang Investasi di Perdagangan Berjangka Komoditi, (Jakarta: PT.BKDI/ICDX, 2013).

Satoshi Nakamoto, "Bitcoin: A Peer-To-Peer Electronic Cash System", www.bitcoin.org, diakses tanggal 07 Oktober 2019.

Zainul Arifin, Dasar-Dasar Manajemen Bank Syariah, (Jakarta: AlvaBet, 2002). 